\title{
Siting Urban Agriculture as a Green Infrastructure Strategy for Land Use Planning in Austin, TX
}

\author{
Charles M. Rogers* and Colleen C. Hiner \\ Department of Geography, Texas State University, San Marcos, TX, USA \\ * Corresponding author: E-Mail: Cmr138@txstate.edu; Tel.: +1 4794458334
}

Submitted: 1 February 2016 | In revised form: 19 July 2016 | Accepted: 19 July 2016 |

Published: 22 August 2016

\begin{abstract}
Green infrastructure refers to a type of land use design that mimics the natural water cycle by using the infiltration capacities of vegetation, soils, and other natural processes to mitigate stormwater runoff. As a multifunctional landscape, urban agriculture should be seen as a highly beneficial tool for urban planning not only because of its ability to function as a green stormwater management strategy, but also due to the multiple social and environmental benefits it provides. In 2012, the city of Austin adopted a major planning approach titled the "Imagine Austin Comprehensive Plan" (IACP) outlining the city's vision for future growth and land use up to 2039. The plan explicitly addresses the adoption of green infrastructure as a target for future land use with urban agriculture as a central component. Addressing this area of land use planning will require tools that can locate suitable areas within the city ideal for the development of green infrastructure. In this study, a process was developed to create a spatially explicit method of siting urban agriculture as a green infrastructure tool in hydrologically sensitive areas, or areas prone to runoff, in east Austin. The method uses geospatial software to spatially analyze open access datasets that include land use, a digital elevation model, and prime farmland soils. Through this method a spatial relationship can be made between areas of high surface runoff and where the priority placement of urban farms should be sited as a useful component of green infrastructure. Planners or geospatial analysts could use such information, along with other significant factors and community input, to aid decision makers in the placement of urban agriculture. This spatially explicit approach for siting potential urban farms, will support the integration of urban agriculture as part of the land use planning of Austin.
\end{abstract}

Keywords: GIS; green infrastructure; urban agriculture; urban planning; watershed protection

\section{Introduction}

\subsection{Green Infrastructure and Urban Agriculture}

The federal Clean Water Act (CWA) of 1972 provided a basic framework for the regulation of pollutant discharges with the intent of protecting water quality and human health in the United States (U.S.) [1]. To further the protective benefits of the CWA, the Environmental Protection Agency (EPA) enacted its Combined Sewer Overflow Control Policy in 1994 [2]. This policy initiative established guidelines by which municipalities could better manage environmentally harmful stormwater pollution events that occurred as a result of infrastructural challenges in handling both sanitary sewage and stormwater runoff in the same sewer system during precipitation events. In response, many cities im- 
plemented green infrastructure measures to help mitigate urban stormwater runoff as an alternative to expensive water main upgrade projects. Green infrastructure can be defined as the management of runoff through the use of natural systems, or engineered systems that act as natural systems, to allow stormwater to infiltrate the ground, recharging the water table and decreasing run-off. According to the EPA, Green infrastructure uses vegetation, soils, and natural processes to manage water and create healthier urban environments. At the scale of a city or county, green infrastructure refers to the patchwork of natural areas that provides habitat, flood protection, cleaner air, and cleaner water. At the scale of a neighborhood or site, green infrastructure refers to stormwater management systems that mimic nature by soaking up and storing water [3]. While this definition of green infrastructure is structured on water management, there are broader definitions of green infrastructure that focus on aspects such as clean air, wildlife habitat, and preservation of forests and grasslands.

With the industrialization of our food systems, most cities, whether intentionally or not, have developed in such a way that farms have become incompatible with the urban environment. There is, however, a tremendous amount of resurgent interest in urban farming and community gardening across the country. In general terms, urban agriculture refers to "the growing, processing, and distribution of food and nonfood plant and tree crops and the raising of livestock, directly for the urban market, both within and on the fringe of an urban area" ([4], p. 2500; [5], p. 4). As evidenced by the recent growth of municipal urban agriculture land inventories as a method to integrate urban agriculture into sustainable land management policy [6], we can infer that municipalities value the multi-beneficial attributes that urban agriculture offers. Urban agriculture has been characterized as a multifunctional land use because, through its versatility as a landscape, it offers a range of benefits to densely populated areas [4]. For example, the ecological functions of urban agriculture provide environmental benefits in the form of biodiversity, nutrient cycling (compost), or wastewater re-use (stormwater and greywater); the cultural functions improve the quality of a neighborhood or community through its visual appeal, recreational use, or the provision of rare foods to immigrant communities; the socio economic functions provide access to nutritious fresh produce for underserved communities in food deserts facing obesity and diabetes [4].

In fact, evidence suggests that incorporating appropriate types of urban agriculture into the urban environment will greatly improve the overall sustainability of U.S. cities [4,7]. The EPA, in collaboration with experts from academia, state and local governments, and nonprofits, released a general listing of the benefits of urban agriculture:

- Increases surrounding property values, beautifies vacant properties, increases a sense of community, and provides recreational and cultural uses [8].

- Increases infiltration of rainwater, reducing stormwater overflows and flooding, decreases erosion and topsoil removal, improves air quality, and reduces waste by the reuse of food and garden wastes as organic material and compost [8].

- Increases physical activity and educates new gardeners on the many facets of food production from food security to nutrition and preparation of fresh foods [8].

While the positive ecological and environmental impacts of urban agriculture have been acknowledged, minimal research has been conducted to determine the feasibility of urban agriculture as a green infrastructure strategy to manage stormwater. Green infrastructure strategies include a list of practices that have been studied and quantified, making their engineering and performance outcomes predictable and reliable [3]. A lack in such quantification, or of carefully researched sets of best management practices, leads to a further lack in the promotion of urban agriculture as a green infrastructure strategy. As Dunn ([9], p. 58) argues: "Being able to quantify the effectiveness of green infrastructure on a small scale is one way to promote regulatory and enforcement acceptance, which thereby enhances its appeal to city officials". As a productive, multifunctional landscape, urban agriculture offers answers to complex infrastructural challenges that are facing many cities.

\subsection{Urban Agriculture Land Inventories}

Over the last decade a variety of municipalities have begun the process of inventorying and assessing land to determine the potential for a broad range of urban agricultural initiatives. This effort is driven by a diverse range of community stakeholders, each with an interest in growing food locally, including capturing the social and environmental benefits urban agriculture provides. Yet, despite the realized and potential benefits for individuals and communities, urban agriculture is largely overlooked in urban and regional planning $[4,10]$. Instead of considering opportunities to preserve farmland or to integrate it as part of a land use management strategy in urban environments, agricultural landscapes are often considered by land use planners as areas for future development [4].

As part of the urban planning process, land inventories have been used and recognized as a basic tool for land suitability and site selection [11]. Many municipalities and researchers are now employing this tool to promote urban agriculture, integrating it into public policy and planning as a land management strategy. Horsts' (2011) paper "A Review of Suitable Urban Agriculture Land Inventories" provides a brief overview of urban agriculture land inventories in various cities [12]. Inventories have been performed in Portland, Vancouver, Seattle, Cleveland-Cuyahoga County, Detroit, Chicago, Toronto, New York City, Cincinnati, Oakland, and San Francisco [12]. Some of the inventories primarily focus on public vacant land and some open up their inventory to include private lands or residential lands such as lawns or rooftops.

Decisions made as part of urban agricultural land inventories typically require the input of multiple criteria involving social, economic, and environmental considerations 
$[6,13,14]$. The success of multiple criteria decision making depends on an array of knowledgeable stakeholders making informed decisions [15]. Using this model, inventories rely upon the explicit use of an advisory committee with representation from municipal staff, non-profit organizations, urban gardeners, and academic researchers. Many inventories emulate the Portland model, wherein an advisory committee guided the inventory throughout the process, particularly in establishing evaluation criteria and reviewing preliminary results. Mendes et al. [6] points to Portland's inventory as more successful when compared to Vancouver due to the way Portland engaged many community partners throughout the entire process, from design to implementation, while Vancouver lacked community involvement. Mendes et al. [6] suggests this represents what the scholarly literature identifies as a "networked movement", where participation in local decision making is inclusive and citizen engagement is fully accepted, similar to Arnstein's [16] highest rungs in the ladder of citizen participation (Partnership, Delegated Power, Citizen Control). Likewise, Oakland established a Community Advisory Committee throughout the project that provided citizen input in a number of areas: the location of potential sites, criteria for selection of potential sites, and feedback on what type of information would be useful in the finished inventory [17]. The best asset mapping has been described, especially in the case of urban agricultural land inventories, to be a multi-stakeholder process for action planning and policy design $[4,6,18]$.

Many of the inventories have involved multiple stakeholders in research and analysis phases, but have been less inclusive when performing technical analysis including Geographical Information System (GIS), aerial imagery assessment, and site visits or ground-truthing [19]. The key actors during this phase of inventory development have been municipal staff, experts from food policy councils and non-profits, and students [12]. The partnership among stakeholders from the city governments and student researchers from local universities has created synergistic opportunities. In Portland, Vancouver, Oakland, Seattle, and Cleveland among others, graduate students worked in partnerships with local municipalities to complete the inventory, thereby gaining valuable experience while the respective cities received cost-effective results.

Generally, the vacant land inventories followed a framework of identifying vacant or open land by ownership type, categorized as public or private, assigning suitability criteria, then eliminating the unsuitable sites and highlighting the best. Within this generalized framework, most inventories created suitability criteria for urban agriculture addressing physical and socioeconomic factors, assigned a ranking or scoring system for criteria, presenting the study results as publicly available reports [19].

The technical work for most inventories made use of one or a combination of methods including aerial photo assessment, GIS analysis, remote sensing, and site visits. Some efforts relied extensively on GIS analysis or remote sensing as in New York and Philadelphia [20,21]. The potential exists for expanding the use of GIS and remote sensing for urban agricultural land inventories from other approaches developed by urban land use researchers. For example, Myeong et al. [22] developed vegetation indexes that estimate vegetation coverage and bare soil, criteria that usually requires labor-intensive visual assessment, using multi-spectral and hyper-spectral data to identify urban green areas [21]. Other inventories have made use of the satellite imagery from the National Agricultural Imagery Program (NAIP) overlaid onto the GIS city parcel data of vacant land in order to select parcels containing potentially arable land [23]. A more specific use of geospatial data in the Halifax, Canada inventory used the LiDAR data to model sun exposure, an important aspect of most inventories suitability criteria for potential urban agricultural sites [23].

As the practice of inventories is evolving, there are areas for improvement. In particular, many authors noted limitations because of incomplete data, limited availability of data, and frequency of updated data [13,21,23,24]. A common limitation expressed by researchers stemmed from low resolution and accuracy of the aerial imagery that resulted in possible visual interpretation errors [13,23]. As a result, researchers advised that post-analysis groundtruthing of potential sites would be necessary to quality check geospatial analysis [13,23]. Additionally, establishing a measure of community support is also an area that many inventories acknowledged needed further research to identify variables such as cultural preferences, skills and willingness, demand, resources, and the presence of local leaders $[21,24,25]$. Inventories with community advisory committees also noted that site visits, community outreach, and consultation with city staff are necessary to evaluate characteristics like soil quality, community interest, and security $[6,14,23]$. Soil quality, in particular, is an issue in many urban areas that was recognized by most inventories as an area for further research and analysis. In Oakland, for example, the completed inventory inspired further research about lead $(\mathrm{Pb})$ contamination in the soil of potential urban agricultural sites. This research assessed $\mathrm{Pb}$ levels at over a hundred different sites identified in the inventory [26].

Beyond land identification, land inventories have been an effective tool to integrate urban agriculture into urban policy and planning as a land management strategy [6]. As a part of the planning process land inventories can identify opportunities for urban agriculture initiatives that result in positive changes. Some impacts have included increasing awareness and political support for urban agriculture, advancing social and ecological sustainability, and enhancing public involvement $[6,17]$. For example, Toronto, Seattle, and Portland experienced notable changes resulting from vacant land assessments. In Toronto, local zoning regulations and guidelines were altered to help guide an increase in urban agriculture [19]. In Seattle and Portland, the collaborative process increased community involvement and inclusion of urban agriculture into city sustainability planning [6]. Stakeholders have also built upon these assessments and conducted more targeted in depth studies that relate 
to issues of public health, economic development, food security, and environmental sustainability [19]. As a tool, land inventories do not have to function in isolation and can be employed in conjunction with other strategies, such as surveys or scenario planning, to advance municipal goals such as stormwater management, reducing carbon emissions, increasing food access, and supporting workforce development [6].

Urban agriculture land inventories have been a useful step for many cities in evaluating the potential for urban agriculture, though the process and resulting impacts are unique to each city. The type of parcels considered, criteria applied, and stakeholders involved differ depending on the objective. The delineation of potential urban agriculture sites is only a preliminary step in a long process of mapping the potential of urban agriculture in a city [23]. That being said, such demarcations can be a useful starting point as cities begin to incorporate urban agriculture into community planning. The tools involved with a land inventory have the potential to facilitate participatory planning by bringing together community participants such as local residents, food activists, academic researchers, and farmers with city planners and government officials, in an effort to better plan and manage land use [4]. Nevertheless, the politics of negotiating competing uses of land is inherently complex and difficult. The viability of utilizing urban agriculture land inventories for planning will depend upon identifying and negotiating the varied interests of multiple stakeholders [23].

\subsection{Can Urban Agriculture identify as Green Infrastructure in Austin, TX?}

In 2012, the City of Austin adopted a major planning approach titled the Imagine Austin Comprehensive Plan (IACP) that outlines the vision for future growth and land use in the city until 2039 . The plan explicitly addresses the adoption of green infrastructure as a targeted future land use with urban agriculture specifically being included as a component of the green infrastructure network.

The IACP identified eight priority programs, ranked in order of importance, which will guide policy and implementation of the plan. The fourth priority proposes the use of "green infrastructure to protect environmentally sensitive areas and integrate nature into the city" [27]:

1. Invest in a compact and connected Austin.

2. Sustainably manage our water resources.

3. Continue to grow Austin's economy by investing in our workforce, education systems, entrepreneurs, and local businesses.

4. Use green infrastructure to protect environmentally sensitive areas and integrate nature into the city.

5. Grow and invest in Austin's creative economy.

6. Develop and maintain household affordability throughout Austin.
7. Create a Healthy Austin Program.

8. Revise Austin's development regulations and processes to promote a compact and connected city.

The building block actions listed as methods to implement the green infrastructure priority program include several references to urban agriculture (below; emphasis added):

- Integrate citywide and regional green infrastructure to include such elements of preserves and parks, trails, stream corridors, green streets, agricultural lands, and the trail system into the urban environment and the transportation network [27].

- Incentivize appropriately-scaled and located green infrastructure and public spaces, such as parks, plazas, greenways, trails, urban agriculture and/or open spaces in new development and redevelopment projects [27].

- Expand regional programs and planning for the purchase of conservation easements and open space for aquifer protection, stream and water quality protection, wildlife habitat conservation, and sustainable agriculture [27].

- Extend existing trail and greenway projects to create an interconnected green infrastructure network that includes such elements as preserves and parks, trails stream corridors, green streets, greenways, and agricultural lands that link all parts of Austin and connect to nearby cities [27].

- Permanently preserve areas of the greatest environmental and agricultural value [27].

This study looks at east Austin where there is 1) an established urban and peri-urban farm presence and 2) high future development potential of agricultural land due to the Austin-Round Rock Metro Area's rapid growth (110 people per day) [28] and lack of land use constraints leading to urban sprawl [28]. Since the late 1990s, the City of Austin has viewed the eastern side of the metro area as a prime area of growth and development. Without an urban growth boundary most of what the city has determined as the "desired development zone" (DDZ) falls into much of east Austin (Figure 1) and beyond into the Austin's Extraterritorial Jurisdiction (ETJ). The opening of the SH130 tollway, conceived of as a north-south alternative route to interstate 35 on the east side of Austin, has further opened up large areas of available land for new jobs, housing, and services for Austin's rapidly growing population. The Imagine Austin plan conceives of growth corridors around the city, with the $\mathrm{SH} 130$ corridor representing one of those growth corridors in east Austin. According to 2012 land use data from the City of Austin, 94,961 acres of undeveloped land, much of it in agriculture, existed in the suburban portion of the DDZ. Information from the 2015 State of the Food System Report, released by the City of Austin's Office of Sustainability, put the loss of farmland each day in Travis County at 9.3 acres and a $25 \%$ loss in farmland over the last 11 years [29]. 


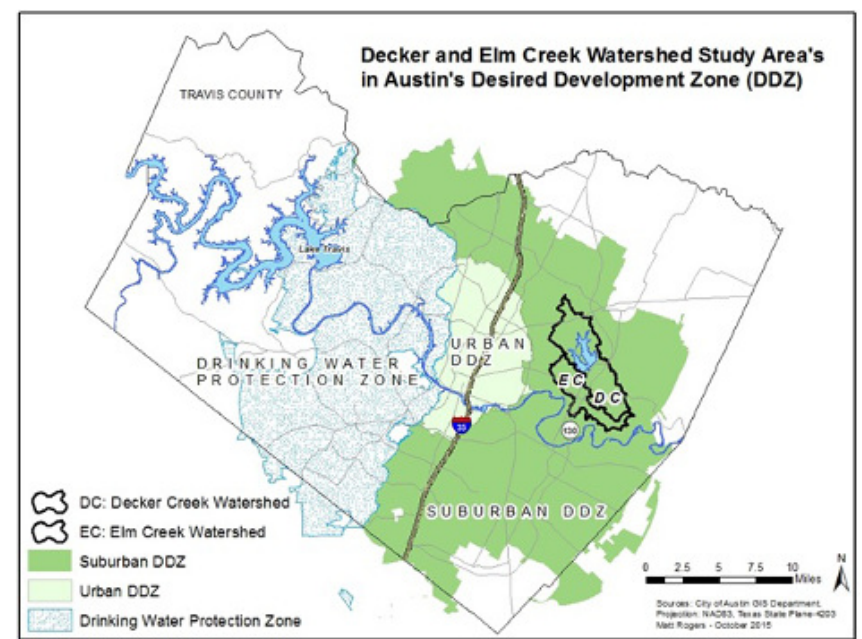

Figure 1. The Decker Creek and Elm Creek Watershed study areas, located in Austin, Texas in Travis County, reside completely in the Suburban DDZ, an area promoted for growth and development by the City of Austin.

Furthermore, the hydrologic environments in east Austin are already under much pressure as a result of being located downriver from the impervious cover of the central business district and at the bottom of several highly urbanized watersheds, effectively making east Austin the hydrologic drain for the city [30]. The creeks and watersheds within east Austin have experienced significant erosion problems and flooding associated with the increasing development and impervious cover seen upstream over the last half century [30]. Further exacerbating the erosion problems have been urban development patterns in the suburban DDZ that situated buildings on small lots close to the creeks. The Austin City Council itself has underscored the potential implications of increasing development and its effect on eastern watersheds:

"The eastern watersheds, with broader floodplains and more erosive soils, pose unique challenges to creek and floodplain protection. Development is currently being placed in close proximity to erosive creek banks in headwaters areas and creating future problems requiring significant and unsustainable public expense to maintain and repair. This development will likely accelerate as build-out proceeds along $\mathrm{SH}-130$ " [31].

As a response to city-wide watershed threats, the City Council updated the watershed protection policies in 2013 with Phase One of the new Watershed Protection Ordinance (WPO). The new WPO increased stream buffers and erosion hazard zones to ensure development is not built to close to waterways for over 400 miles of smaller headwater streams [32]. Phase Two of the WPO began in January 2015 with a Green Infrastructure Working Group as part of the City's land development code rewrite process, called CodeNEXT, to discuss how to achieve the Imagine Austin goals of "integrating nature into the city and creating complete communities through revisions to our zoning and environment codes' [32]. Currently, green infrastructure techniques in the Watershed Department's manual for best management practices include rain gardens, bio- filtration areas, and vegetative filter strips; however, there is no reference to urban agriculture as a green infrastructure strategy for new development or as a stormwater management strategy in the city.

Nevertheless, within the last twenty years there has been a proliferation of urban agriculture in east Austin. A variety of urban agriculture exists in the city, ranging from community gardens to small market farms (defined as farms operating on less than one acre within the city's full jurisdictional boundary) to larger urban farms (over one acre) within or on the periphery of the city. In addition, the Austin City Council has encouraged urban agriculture by authorizing relaxed zoning regulations for private urban farms. For example, the current land code allows for urban farming in all zoning classes, and, at this time, there are 23 urban farms in the city of Austin, classified either as "market farms" if less than one acre and as "urban farms" if more than one acre, and 52 community gardens [29]. Furthermore, in 2009, the Austin City council created the Sustainable Urban Agriculture and Community Garden Program with the expressed purpose of streamlining the process for establishing community gardens and sustainable agriculture on city land, further endorsing urban agriculture in the city.

Much of the land in the suburban DDZ is in Texas Blackland Prairie Geographic Region and contains prime farmland soils according to the classification by the National Resources Conservation Service (NRCS) (Figure 2). The soils in this region are known for being deep and rich with organic material, making them valuable for agricultural use [33]. With the quality of the soils, good drainage, and flat surface, prime farmland also serves as ideal land for development. Indeed, many new developments are going to occur in prime farmland as a result of the city's priority to develop in the suburban DDZ and the substantial amount of open space in that part of the city. As a matter of debate, the question is how much of the land to develop and what positive and negative impacts are expected to occur. However, the City of Austin, through its Imagine Austin plan, has indicated that preserving a portion of different classifications of open land is important for making Austin a sustainable city. The function of urban agriculture in this plan, thus, has significance in terms of protecting and valuing the environmental, social, and economic well-being of Austin. Most significantly for this study, though, is the role of urban agriculture as a means to conserve prime farmland and serve as green infrastructure in Austin.

\subsection{Purpose of Study}

Urban agriculture acts as a multifunctional landscape with a variety of benefits including the ability to offset many facets of environmental degradation including preventing excessive runoff [34]. The increase of new development and predominance of urban farms in east Austin, combined with the rise of green infrastructure as a stormwater management focus in the city, makes east Austin an ideal study area for evaluating the potential role of urban agriculture as a green infrastructure strategy. While this is the narrow aim of this study, the true value of urban agriculture as green infrastructure can only be better understood by placing the results of this research into a wider systems framework that encompasses the multiple environmental, economic, and social benefits offered by urban farms. 


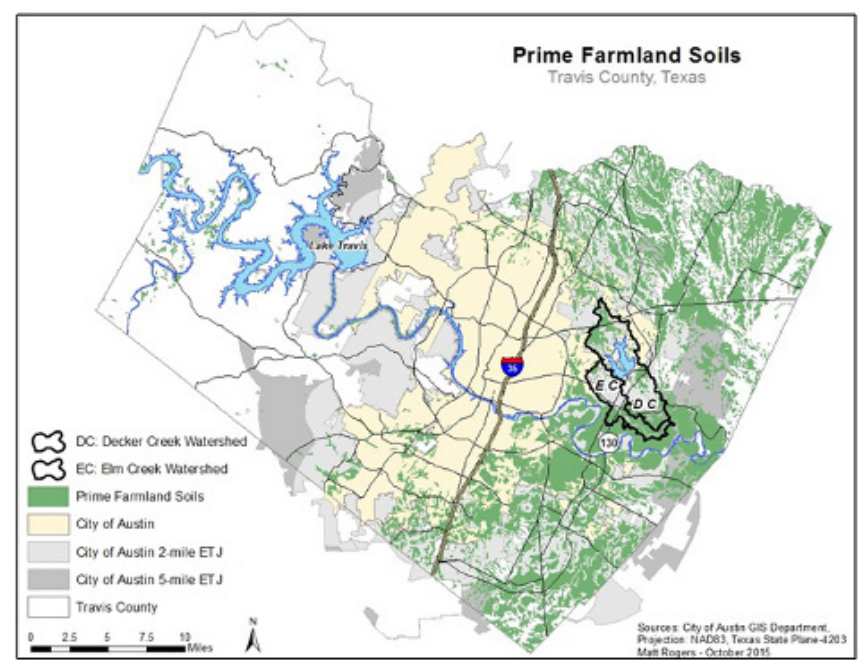

Figure 2. Prime Farmland Soils in Austin, Texas almost exclusively exist in east Austin, where the City of Austin is encouraging growth and development to occur as part of the Suburban DDZ.

The Imagine Austin plan explicitly addresses the adoption of green infrastructure as a targeted future land use with urban agriculture as a component of the green infrastructure network. Addressing this area of land use planning will require tools that can locate suitable areas within the city where urban agriculture can best act as green infrastructure. In this study, a process was developed to create a spatially explicit method of siting urban agriculture as a green infrastructure tool on hydrologically sensitive areas (HSAs), or areas prone to runoff, in east Austin. The method uses geospatial technology to spatially analyze open access datasets that include land use, a digital elevation model, and prime farmland soils. Through this method a spatial relationship can be made between areas of high surface runoff and where the priority placement of urban farms should be sited as a useful component of green infrastructure. Planners or geospatial analysts could use such information, along with other significant factors and community input, to aid decision makers in the placement of urban agriculture. Creating a spatially explicit approach for siting potential urban farms will support the integration of urban agriculture as part of the sustainable land use planning of Austin.

\section{Data and Methods}

\subsection{Study Area}

This study examines the sub-watersheds of Decker Creek and EIm Creek in east Austin (Figure 1). These two watersheds were chosen because they are smaller watersheds that both exist completely within the suburban DDZ and reside in either the Full Purpose Jurisdiction or ETJ of Austin, whereas other eastern watersheds do not fit within those parameters. In addition, the $\mathrm{SH} 130$ growth corridor cuts through both watersheds as well as the FM 969 growth corridor. The impact of growth in the region and the expected loss of prime farmland and agricultural land use make these two watersheds ideal areas to study. Decker Creek watershed is 17 square miles and Decker Creek runs 12 miles from the top of the watershed to the outlet. Decker Creek watershed is less developed than other watersheds in Austin containing more agricultural land, but is projected to experience a rise in population growth from 3,156 people in 2000 to 12,341 people in 2030 or a $391 \%$ projected increase [35]. Elm Creek watershed totals only 9 square miles and Elm Creek runs 10 miles from the headwaters to the outlet [35]. Elm Creek watershed is comprised mostly of agricultural land, though with development looming there will be an expected increase in population of $180 \%$, or from 3,136 residents in 2000 to 5,643 residents in 2030 [35]. By analyzing these watersheds, the study examines where current farmland can best be preserved for urban agriculture, especially in light of the area's continued development, and provides insight into the functionality of urban agriculture as a way to reduce surface runoff pressure on developing watersheds.

\subsection{Data Sourcing \& Methods}

The entirety of the data for the geospatial elements of this project were sourced from open access datasets (Table 1). Data was pulled from the "GIS Downloads" website managed by the City of Austin. Other data was pulled from federally managed "Data Download" map viewers. The digital elevation model (DEM) was downloaded from the National Map Viewer managed by the United States Geologic Survey. Soil data was obtained from the Web Soil Survey Map Viewer managed by the National Resources Conservation Service (NRCS). Aerial imagery was downloaded from the National Agriculture Imagery Program (NAIP) and land cover data came from the National Land Cover Database (NLCD). Additional data and information about study area context were derived from informal interviews with urban farmers and City of Austin leadership, together with a site visit to an urban farm within the study area. The human subject's portion of this research was approved by the Institutional Review Board (IRB) exemption request on October 15, 2015 with ID \# L4567180. 
Table 1. Data layers used to inventory urban agriculture and create a topographic index at a watershed scale.

\begin{tabular}{lll}
\hline GIS Layer & Format & Source \\
\hline Land Use 2012 & Vector-polygon & City of Austin GIS Downloads (2012) \\
Watersheds & Vector-polygon & City of Austin GIS Downloads (2013) \\
Digital Elevation Model (DEM) & 10 meter/raster & National Elevation Dataset- Geospatial Data Gateway \\
Soil Conductivity & Vector-polygon & Soil Survey Geographic Database: National Resources Conservation Service. \\
Soil Depth to Restrictive Layer & Vector-polygon & Soil Survey Geographic Database: National Resources Conservation Service. \\
Prime Agricultural Soils & Vector-Polygon & Soil Survey Geographic Database: National Resources Conservation Service. \\
Aerial Imagery & 1 meter/raster & Texas Natural Resources Information System: National Agriculture Imagery Program \\
\hline
\end{tabular}

\subsection{Geospatial Database Development}

For use in this analysis, all datasets were projected to the North American Datum 1983 (NAD83), State Plane Texas4203 with a Lambert Conformal projection to coincide with data from the City of Austin. Both the soils and land use data had to be transformed from vector to raster to correspond with other raster layers. In particular, the prime farmland data and the land use data needed transformation to perform a simple urban agricultural inventory that would be combined with another raster dataset.

Furthermore, a topographic index was performed to delineate HSAs, areas that are prone to generate surface runoff, within the Decker Creek and Elm Creek watersheds. The topographic index is determined with a GIS and requires a digital elevation model, soil hydraulic conductivity, and depth of soil to restrictive layers [36-38].

\subsection{HSA Delineation}

The topographic index $(\lambda)$ is formed from two components. The first component is a steady state wetness index, formulated from slope $(\beta)$ and drainage area $(\alpha)$ of the watershed [36-38]. This index determines the potential for surface runoff within the contributing area and for each cell within the raster. The steady state wetness index is defined as:

$$
\ln \frac{\alpha}{\tan \beta}
$$

where $\alpha$ is the drainage area per unit contour length in meters and $\beta$ is the slope in radians.

The second component is soil water storage, derived from soil hydraulic conductivity $\left(K_{s}\right)$ and soil depth to restrictive layers (D) [36-38]. Soil water storage determines the saturation probability for each cell in the raster. Soil water storage is expressed as:

$$
\ln \left(K_{s} D\right)
$$

where is the soil hydraulic conductivity in meters per day and is the soil depth to restrictive layers in centimeters. In general, the deeper the soil depth or topsoil, and the higher the value of the soil hydraulic conductivity or the speed at which water percolates through the ground, the lower the likelihood of producing surface runoff [39].
The two components combine to make the soil topographic index equation, below, to determine the hydrologically sensitive areas in the watershed:

$$
\lambda=\ln \frac{\alpha}{\tan \beta}-\ln \left(K_{s} D\right)
$$

To calculate the steady state wetness index, a 10-m resolution DEM, clipped to the watershed, was processed by an open source tool, called the Compound Topographic Index (CTI), as part of an ArcGIS extension toolset. This extension allows the user to simply input a DEM into the CTI tool automatically calculating the steady state wetness index according to the first component of the soil topographic index equation. The CTI operates exactly like the steady state wetness index component of the equation above and can be shown as:

$$
C T I=\ln \frac{\alpha}{\tan \beta}
$$

where $\alpha$ is drainage area "calculated as (flow accumulation $+1) \times\left(\right.$ pixel area in $\mathrm{m}^{2}$ )" [40] and $\beta$ is "the slope expressed in radians" [40].

At this point, the raster layers for each component part of the topographic index equation were entered into the ArcGIS Raster Calculator to calculate the HSAs of the watersheds. The resulting raster layer indicates areas within the 10-m grid that are more or less likely to become saturated when a storm event occurs. The higher topographic index $(\mathrm{TI})$ values correspond to areas most likely to become saturated and act as a source of surface runoff, also indicating the location of hydrologically sensitive areas $[37,39]$. During a storm event, runoff would likely accumulate and disperse in areas with higher topographic indices than any areas with lower topographic indices [39].

Hydrologically sensitive areas are areas most prone to surface runoff and must be delineated in a watershed by some threshold criteria to identify as distinct from the lower topographic indices that are less likely to produce runoff [36-38]. Many techniques have been used to derive such conclusions. Agnew et al. [36] proposes using the average saturation probability to determine HSAs. Others have used the delineation tactic of targeting $20 \%$ of the watershed with the highest topographic index values to prevent overland flow from reaching streams [39]. Community and stakeholder involvement also represents a method of delineating 
HSAs based on funding, feasibility, or local expertise. Qui [39] selected an HSA threshold level for illustrative purposes considered as reasonable and Martin-Mikle [37] expanded upon that criteria by selecting TI values 1.5 standard deviations above the mean as HSAs. Following similar protocol, HSAs in this study were delineated by selecting topographic index values 1.5 standard deviations above the mean for each respective watershed. Decker Creek watershed TI values have a mean of 11.65 , resulting in a threshold $\mathrm{TI}$ value level of 15 . Any grids in Decker Creek with a TI value greater than or equal to 15, therefore, are delineated as HSAs. The threshold value for selection of HSAs in Elm Creek is anything above 14 , or 1.5 standard deviations above the mean value of 10.20 .

\subsection{Delineation of Prime Farmland on Agricultural Land Use}

To determine where current land use is best suited for transitioning into some form of urban agricultural opportunity, a simple urban agriculture land inventory was performed in both watersheds. This land inventory was derived from two datasets: City of Austin land use data and prime farmland soil data from the National Resources Conservation Service SSURGO soil database. Utilizing the ArcGIS 10.2 overlay analysis tools on the aforementioned datasets resulted in a new dataset of potential land suitable for urban agriculture. The inventoried lands suitable for potential urban agriculture are located on prime farmland soils and have an agricultural land use classification.

\subsection{Combining HSAs with Land Use and Prime Farmland Data to Prioritize Locations for Urban Agriculture as Green Infrastructure}

To prioritize locations for urban agriculture as a green infrastructure tool, the urban agriculture land inventory, composed of land use and prime farmland data, had to be converted to a raster layer to enable a combination of the delineated HSAs in each watershed with TI values 1.5 standard deviations above the mean. In the Decker Creek watershed, TI values greater than or equal to 15 were overlaid onto the potential areas for urban agriculture to find HSAs located on agricultural land use and prime farmland soils. In the Elm Creek watershed, TI values greater than or equal to 14 were overlaid onto the potential areas for urban agriculture to find HSAs located on agricultural land use and prime farmlands soils. The resulting datasets showed where in each watershed agricultural land use and prime farmland soils should be considered as areas for potential urban agriculture as a green infrastructure tool according to the spatial relationship with HSAs in the watershed. To further prioritize the sites considered as potential sites for urban agriculture as a green infrastructure strategy and for conserving prime agricultural land in Austin, an additional step derived the top ten areas in each water- shed holding the most HSAs in acreage according to Travis County Appraisal District (TCAD) parcels. TCAD parcels identify bounded property lines in Travis County and their owners.

\subsection{Combining Prioritized Locations of Urban Agriculture with TCAD Parcels to Identify Sites with the Most HSA Acreage}

TCAD parcels from the City of Austin were downloaded and clipped to each respective watershed to delineate the boundaries of the parcels within the watershed. The application of the ArcGIS spatial analyst tool zonal statistics derived how many 10 meter pixels of HSAs on potential urban agriculture sites were located within the boundaries of individual TCAD parcels. Parcels with no HSAs were eliminated from analysis. Calculations utilizing the field calculator in ArcGIS were then made on the parcels containing HSAs to derive the total amount of HSAs acreage within each parcel. Through sorting, a ranked list of parcels containing the most HSAs acreage was generated for each watershed. This list shows the most viable parcels so that a structured attempt can be made to identify those landowners that hold the most HSAs in an effort to conserve areas of prime agricultural land from incoming development and locate possible urban agriculture opportunities as a method of green infrastructure.

\section{Results}

\subsection{Delineated HSAs on Agriculture Land Use and Prime Farmland}

The derived $\mathrm{TI}$ values for Elm Creek watershed range from 3.5 to 23.3, while the TI values for Decker Creek watershed range from 3.3 to 27.0. In Elm Creek watershed, areas with TI values greater than or equal to 14 (1.5 standard deviations above the mean) are delineated as HSAs (Figure 3). In Decker Creek watershed, areas with TI values greater than or equal to 15 (1.5 standard deviation above the mean) are delineated as HSAs (Figure 4). HSAs indicate areas prone to surface runoff as a function of a topography's slope and drainage area and a soil's saturation potential derived by soil hydraulic conductivity and soil depth. To prioritize where potential urban agriculture sites could serve as a green infrastructure strategy in both watersheds, HSAs were combined with areas deemed as agricultural land use by the City of Austin and those containing prime farmland soils. The total area of agricultural land use on prime farmland for Elm Creek watershed is 1218 acres and 1504 acres for Decker Creek watershed (Table 2). The areas of the delineated HSAs within potential sites for urban agriculture as a green infrastructure tool are 62.7 and 111.7 acres for Elm Creek and Decker Creek, respectively. HSAs represent $5.1 \%$ and $7.4 \%$ of the total agriculture land use on prime farmland in EIm Creek and Decker Creek, respectively. 


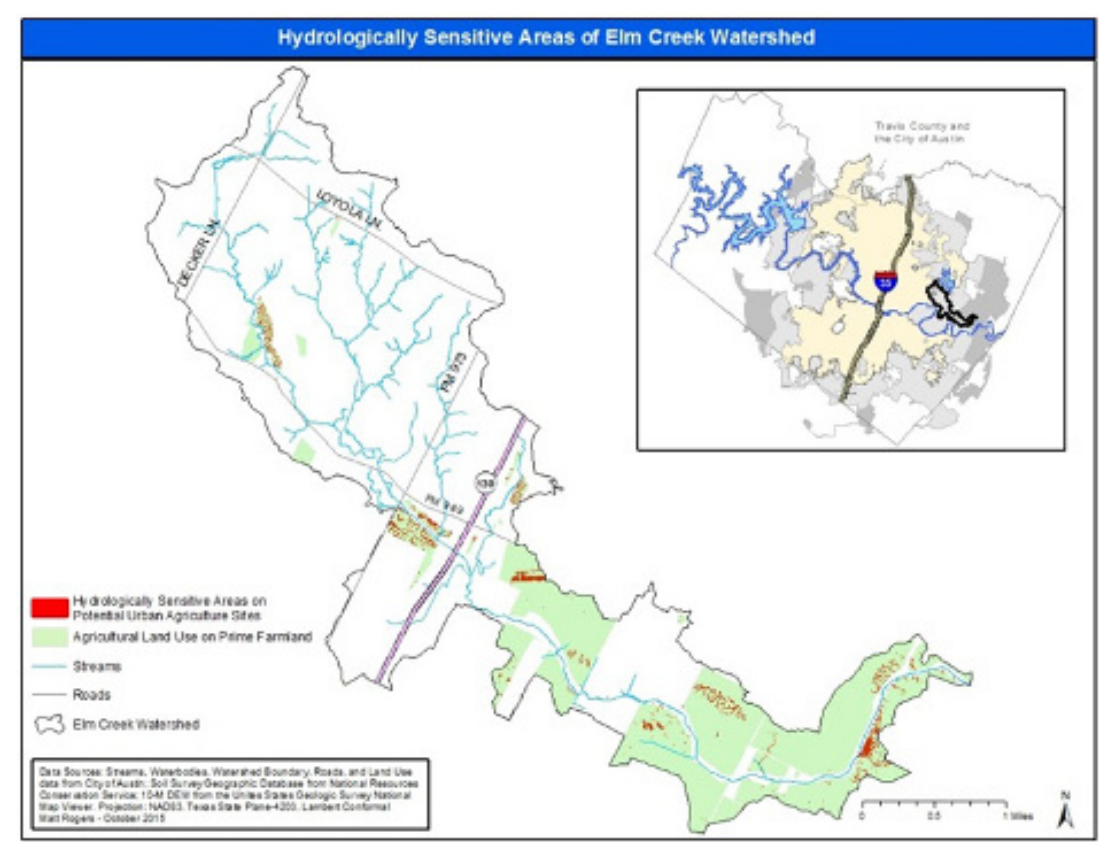

Figure 3. The spatial distribution of hydrologically sensitive areas (HSAs) in Elm Creek Watershed in Austin, TX. HSAs in Elm Creek watershed have topographic index (TI) values 1.5 standard deviations above the mean or greater than 14. These particular HSAs are on potential urban agriculture sites as determined by their location on land deemed agricultural by the City of Austin and considered prime farmland by the National Resources Conservation Service (NRCS).

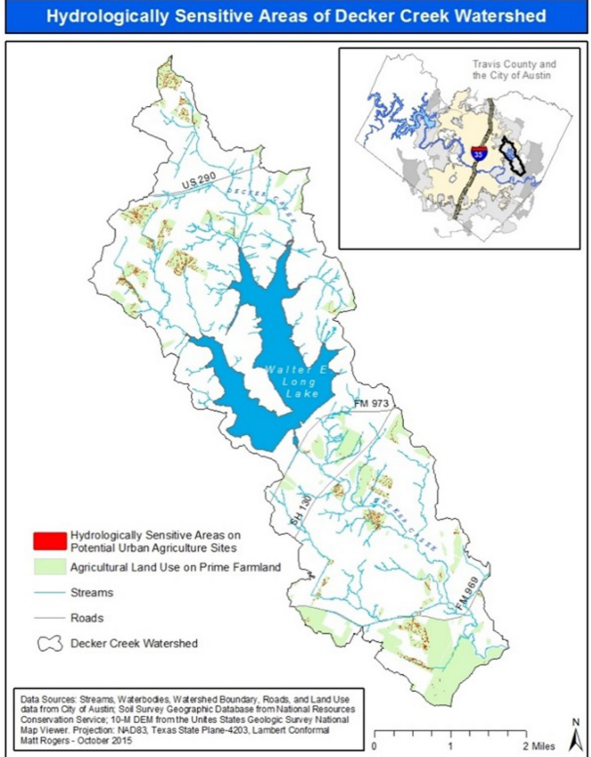

Figure 4. The spatial distribution of hydrologically sensitive areas (HSAs) in Decker Creek Watershed in Austin, TX. HSAs in Decker Creek watershed have topographic index (TI) values 1.5 standard deviations above the mean or greater than 15. These particular HSAs are on potential urban agriculture sites as determined by their location on land deemed agricultural by the City of Austin and considered prime farmland by the National Resources Conservation Service (NRCS).

Table 2. Potential urban agriculture land totals in Elm Creek and in Decker Creek watersheds: agricultural land use on prime farmland, HSAs on prime farmland with agricultural land use, and HSAs on prime farmland with agricultural land use without Critical Water Quality Zone (CWQZ) restrictions.

\begin{tabular}{lll}
\hline & Elm Creek Watershed & Decker Creek Watershed \\
\hline Total Acreage of Agricultural Land Use with Prime Farmland & 1504 acres & 1218 acres \\
Total Acreage of HSAs on Agricultural Land Use with Prime Farmland & 62.7 acres & 111.7 acres \\
Total Acreage of HSAs in CWQZ & 20.4 acres & 17.5 acres \\
Total HSAs left after CWQZ restrictions omitted & 42.3 acres & 94.2 acres \\
\hline
\end{tabular}

\subsection{Delineated HSAs Protected Under Current Land Use Control}

The Critical Water Quality Zone (CWQZ) restrictions set forth by the City of Austin's 2013 watershed protection ordinance restricts development around waterways by establishing a buffer associated with the size of the waterway [41]. The suburban DDZ watersheds, including Decker Creek and EIm Creek watersheds, maintain unique buffer classifications associated with the size of the waterways. In minor waterways, CWQZ boundaries are located 100 feet from the centerline of a waterway [41]. Intermediate waterways retain CWQZ boundaries
200 feet from the centerline of a waterway [41]. Finally, major waterways have a restriction of no development within 300 feet of the CWQZ [41].

The areas of the delineated HSAs found on prime farmland with agricultural land use that are already protected under CWQZ restrictions total 20.4 acres for the Elm Creek watershed (Table 2) and 17.5 acres for Decker Creek watershed (Table 2). With the Elm Creek watershed that leaves 42.3 acres of HSAs on prime farmland with agriculture land use unprotected from potential development (Table 2). While, in the Decker Creek watershed 94.2 acres of HSAs remain unprotected from future development (Table 2). 


\subsection{Prioritized HSAs on TCAD Parcels}

In an effort to include tangible results for the City of Austin (as suggested by the Food Policy Manager at the Office of Sustainability) so that they may reach out to landowners about conserving portions of their land to incoming developmental threat, TCAD parcels were sorted into a "top ten list" of areas that contain the most HSAs. These areas not only hold the potential to serve as urban agricultural opportunities, protecting prime farmland, but also to act as a green infrastructure land use control that further protects the watershed beyond the CWZQ zone.

In both watersheds, the spatial distribution of the HSAs in the parcels varies because the parcels are based on an individual's ownership. As a result, some of the parcels show an even spread of HSAs throughout the parcel, while other locations show clusters of HSAs only in portions of the parcel. As a means of validation, aerial imagery from the National Agricultural Imagery Program (NAIP) and land use data from the National Land Cover Database (NLCD) were used to identify land use within the parcels to validate potential urban agriculture sites.

The top ten parcels in Elm Creek watershed contain 51.5 acres, or $82 \%$, of all HSAs. The total acreage for HSAs ranges from 10.7 acres in Parcel 1 down to 1.9 acres in Parcel 10 (Table 3). In Parcel 1, a mid-size parcel containing 57 acres, the HSAs spread throughout the parcel in an even density, while in most others the HSAs cluster in certain areas of the parcel. Parcel 1 encompasses 41 acres of prime farmland and $26 \%$ of that land contains HSAs. With the relative density of HSAs in Parcel 1, this parcel may best be conserved as an entire plot suitable for a large urban farm. Verification with NAIP imagery and land cover data from the NLCD, demonstrates that this plot contains a large pasture and hay field with HSAs (Figure 5). In contrast, Parcels 2 and 3 contain 8.9 and 7.3 acres of HSAs, respectively, but include only a minimal percentage of HSAs relative to their total percentage of HSAs on agricultural land use with prime farmland. For example, Parcel 2 has 132 acres of agricultural land use on prime farmland but only $6.8 \%$ contain HSAs. The HSAs are highly clustered in the southeast portion of the parcel and, through NAIP and NLCD verification, the densest network of HSAs lies on cultivated fields (Figure 5). In this case, it would make sense to target the portion of the land with HSAs for conservation, adding protection to the watershed by allowing it to remain free of development, enabling it to become a potential site for urban agriculture.

In contrast to Elm Creek, the top ten parcels in Decker Creek watershed encompass a total of 57.5 acres of HSAs, or $51 \%$, of all delineated HSAs in the watershed. Delineated HSAs in the Decker Creek watershed parcels range from a total of 11.1 to 2.9 acres (Table 4). The spatial distribution of HSAs in the Decker Creek watershed parcels vary, though in the northwest corner of the watershed five parcels feature somewhat evenly spread out HSAs. Through validation with NAIP imagery and NLCD data, Parcels 6 and 7, in the northwest corner, contain HSAs primarily on cultivated fields, and have 4.6 and 4.0 acres of HSAs, respectively (Figure 6). Parcel 6 contains only prime farmland and 93\% of the land in parcel 7 is prime farmland (Table 4). The percent of HSAs on prime farmland is $14.5 \%$ for parcel 6 and $18.9 \%$ for parcel 7 . These two parcels, taken together as an urban agriculture site, could protect 8.6 acres of HSAs and 52.8 acres of prime farmland. As a contrast, parcel 8 contains 2.9 acres of HSA, but when verified through NAIP imagery and NLCD data, most of the HSAs are located on uncultivated fields within deciduous forest and scrubland (Figure 6). While maintaining this area as open land, protected from development, still has benefits for the watershed, its use as a potential site for urban agriculture as a green infrastructure strategy may not be the best use of the land. Rather, leaving the land undeveloped arguably poses the greatest benefit to the watershed.
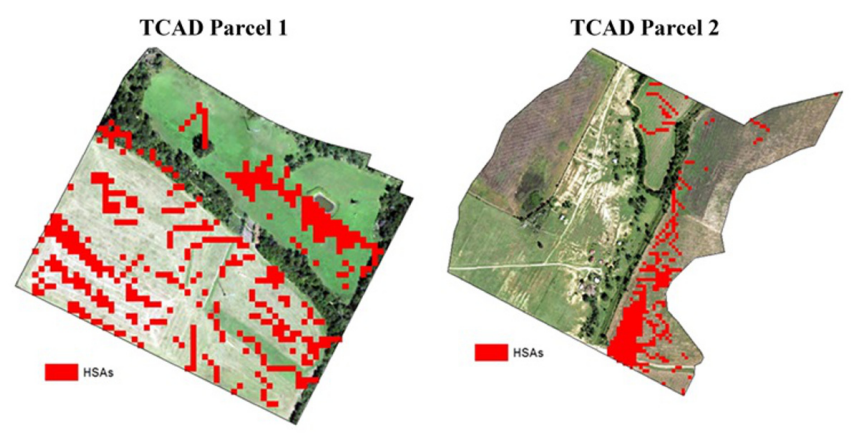

Figure 5. TCAD parcels in Elm Creek watershed. TCAD parcel 1 shows an even spread of HSAs across the land area, while TCAD parcel 2 shows a clustering of HSAs in the southeast portion of the parcel.

Table 3. Potential urban agriculture sites in Elm Creek watershed relative to their affiliation with TCAD parcels and the HSAs located on agricultural land use with prime farmland (Prime Ag).

\begin{tabular}{|c|c|c|c|c|c|}
\hline \multicolumn{6}{|c|}{ Elm Creek Watershed } \\
\hline $\begin{array}{l}\text { TCAD } \\
\text { Parcel }\end{array}$ & $\begin{array}{l}\text { HSAs } \\
\text { acreage }\end{array}$ & $\begin{array}{l}\text { Total } \\
\text { Land } \\
\text { Acreage }\end{array}$ & $\begin{array}{l}\text { Prime } \\
\text { Ag } \\
\text { Acres }\end{array}$ & $\begin{array}{l}\text { Percent of } \\
\text { HSAs on } \\
\text { Total Land } \\
\text { Acreage }\end{array}$ & $\begin{array}{l}\text { Percent of } \\
\text { HSAs on } \\
\text { Prime Ag } \\
\text { Acres }\end{array}$ \\
\hline 1 & 10.7 & 57.4 & 41.3 & 18.60 & 26.00 \\
\hline 2 & 8.9 & 147.3 & 132.3 & 6.10 & 6.80 \\
\hline 3 & 7.3 & 275.4 & 256 & 2.70 & 2.90 \\
\hline 4 & 5.4 & 165.1 & 154.3 & 3.30 & 3.50 \\
\hline 5 & 4.4 & 82.2 & 60.5 & 5.40 & 7.30 \\
\hline 6 & 4 & 29.5 & 19.2 & 13.60 & 20.80 \\
\hline 7 & 3.5 & 79 & 75 & 4.40 & $4.70 \%$ \\
\hline 8 & 2.8 & 27.2 & 9.2 & 10.10 & 29.90 \\
\hline 9 & 2.6 & 42.4 & 33.2 & 6.10 & 7.80 \\
\hline 10 & 1.9 & 20.6 & 20.6 & 9.40 & 9.40 \\
\hline
\end{tabular}



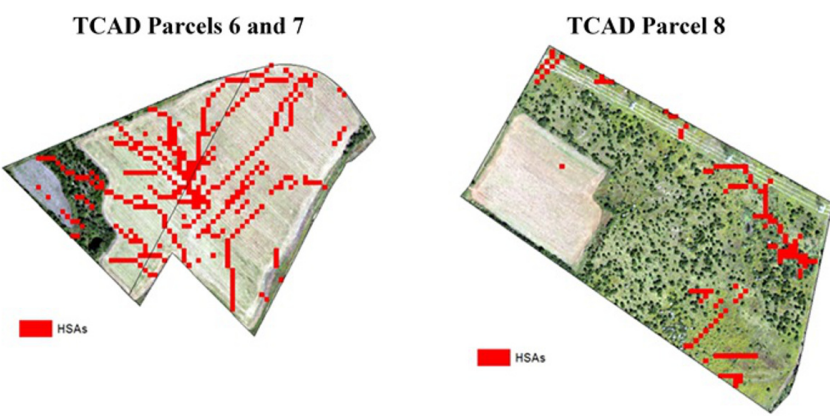

Figure 6. TCAD parcels in Decker Creek watershed. TCAD parcel 6 and 7 show an even spread of HSAs across a cultivated land area, while TCAD parcel 8 shows an uneven spread of HSAs mostly in a landscape of deciduous forest and scrubland.

Table 4. Potential urban agriculture sites in Decker Creek watershed relative to their affiliation with TCAD parcels and the HSAs located on agricultural land use with prime farmland (Prime Ag).

\begin{tabular}{|c|c|c|c|c|c|}
\hline \multicolumn{6}{|c|}{ Decker Creek Watershed } \\
\hline $\begin{array}{l}\text { TCAD } \\
\text { Parcel }\end{array}$ & $\begin{array}{l}\text { HSAs } \\
\text { acreage }\end{array}$ & $\begin{array}{l}\text { Total } \\
\text { Land } \\
\text { Acreage }\end{array}$ & $\begin{array}{l}\text { Prime } \\
\text { Ag } \\
\text { Acres }\end{array}$ & $\begin{array}{l}\text { Percent of } \\
\text { HSAs on } \\
\text { Total Land } \\
\text { Acreage }\end{array}$ & $\begin{array}{l}\text { Percent of } \\
\text { HSAs on } \\
\text { Prime Ag } \\
\text { Acres }\end{array}$ \\
\hline 1 & 11.1 & 89.1 & 66.8 & 12.40 & 16.60 \\
\hline 2 & 8.5 & 66.4 & 48.1 & 12.70 & 17.60 \\
\hline 3 & 7.8 & 72 & 46.9 & 10.80 & 16.60 \\
\hline 4 & 7.1 & 100.3 & 68.9 & 7.10 & 10.30 \\
\hline 5 & 5.7 & 38.1 & 31.7 & 15.10 & 18.10 \\
\hline 6 & 4.6 & 31.7 & 31.7 & 14.50 & 14.50 \\
\hline 7 & 4 & 22.6 & 21.1 & 17.70 & 18.90 \\
\hline 8 & 2.9 & 66.3 & 32.3 & 4.40 & 9.10 \\
\hline 9 & 2.9 & 101.3 & 89 & 2.90 & 3.20 \\
\hline 10 & 2.9 & 31.5 & 13 & 9.20 & 22.20 \\
\hline
\end{tabular}

\subsection{Delineated HSAs on Urban Farms}

Green Gate Farms is a five-acre farm and the only classified urban farm in the Elm Creek watershed. The owners currently rent the land to farm from an owner who holds 106 acres of the land in the Elm Creek watershed. Analysis of the HSA data in the Elm Creek watershed results in no delineated HSAs within the boundaries of the farm. When HSAs are classified as existing on prime farmland with a TI value greater than or equal to 14 , there are still no HSAs in the farm boundary, but there are 7.7 acres of HSAs within the wider 106 acre boundary under scrutiny. The densest network of HSAs resides within just 150 feet of the farm boundaries in an open field adjacent to the farm. When the CWQZ is accounted for, 2.5 acres of HSAs are protected from development leaving 2.2 acres of HSAs unprotected still within a dense network neighboring the farm.

Tecolote Organic Farm is the only urban farm within the
Decker Creek watershed. It comprises 65 acres in total and contains 0.5 acres of HSAs on prime farmland. There are only two $10 \mathrm{~m}$ pixels within the CWQZ accounting for protection of four one-hundredths of an acre. In effect, Tecolote Organic Farm is protecting 0.46 acres of HSAs on prime farmland or $92 \%$ of the total HSAs. When HSAs are delineated solely by a TI value greater than or equal to 15 and not according to land use classification or prime farmland, HSAs total 2.1 acres on the farm.

\section{Discussion}

The Decker Creek and Elm Creek watersheds reside on the periphery of Austin and remain relatively undeveloped at this point. However, city projections suggest the watersheds will be rapidly urbanizing in the near future as Austin continues to increase in population and expand its urban impervious cover. The implication that much of the land in the suburban DDZ will be developed at some point poses a significant threat to those watersheds and open land within them including areas that hold value as prime farmland. Given population growth demands, it will be important to grow smartly, identifying areas best suited for development and organized around interconnected open spaces that protect the environment and add a social and economic benefit as integrated elements of a community, neighborhood, and city. The IACP provides the framework for this type of smart growth in Austin but will need to be implemented through new sets of land use controls and tools that allow planners and decision makers to make informed decisions about where to develop and where not to develop. As the city redevelops its land development code and initiates Phase Two of the WPO concerning green infrastructure, tools such as the one outlined in this research can provide valuable information to incorporate urban agriculture as part of the green infrastructure strategy in Austin.

\subsection{Implementation of Urban Farms on HSAs: Best Management Practices (BMPs)}

The approach outlined in this research prioritized HSAs by their spatial connection to potential urban agriculture sites that could act as a green infrastructure tool. HSAs in a watershed generate overland runoff and require land uses that limit the amount of water resource degradation. High-intensity urban land uses placed on HSAs such as a commercial development or low-density residential development have a significant impact on watershed degradation. For example, an increase in impervious cover increases the amount of stormwater runoff already generated in the area resulting in potential floods, incised creek beds, or more non-point source pollutant loads from residential lawns, leaking septic systems, or carbon particulates from streets and parking lots [38]. Furthermore, common stormwater infrastructure such as catch basins, detention basins, pipes and culverts quickly disperses polluted stormwater runoff to downstream waterways. Urban farms can decrease the 
amount of surface runoff that would otherwise flow to an already overwhelmed storm drain by remaining as undeveloped land and increasing the amount of water that the land can soak up. HSAs on potential urban agricultural land protect the watershed by keeping it as low-intensity land use, with the proper BMPs.

Traditional farming techniques typically have negative impacts on water quality due to farming practices such as fertilization along with pesticides and herbicide use. As a result, HSAs in agricultural land uses have a higher potential to export pollutants from agriculture fields to streams. If HSAs were to be located on potential sites for urban agriculture, it would be necessary to implement BMPs that provide risk reduction techniques to reduce contamination of stormwater runoff from urban farms. Below are some of the best practices for urban agriculture $[38,42,43]$ :

- Use organic farming principals that require no synthetic pesticides or fertilizers;

- Construct berms along the edges where the impervious surface and farm meet to prevent erosion and runoff;

- Incorporate bio swales and retention ponds to collect runoff and promote infiltration;

- Use crop rotation and plant cover crops to hold soil in place;

- Avoid input of animal manure, instead use organically produced compost as a fertilizer;

- Install a rainwater re-use system that captures rainwater then filters it into an underground tank for irrigation use.

Real Food Farm is an example of a farm that integrates stormwater management practices into urban farming. The farm is located in Baltimore, Maryland, in the Chesapeake Bay watershed, a watershed affected by the urbanization of the area leading to large amounts of polluted stormwater runoff. The farm installed a rainwater re-use system that captures rainwater off the hoop houses and stores it an underground cistern. Additionally, the farm incorporated a retention pond and constructed bio swales and berms to help mitigate stormwater runoff from the farm [43].

Another BMP model that the City of Austin could potentially implement for urban farms is a sediment and erosion control plan. Seattle's urban farm code requires a management plan if an urban farm exceeds 4,000 square feet [44]. One provision included within that plan states a given proposed sediment and erosion control program for farmers to follow. To approve a farm, the city considers the potential impacts and mitigation of how a farm's proposed sediment and erosion control measures will affect the impacts of runoff on the surrounding watershed. In addition, Seattle resides in the King County Conservation District which provides free soil nutrient testing on up to five samples, including compost [44]. This program allows farmers to use soil amendments wisely in an effort to reduce water pollution from over-fertilization.

In a sheer size comparison, traditional farms compared to urban farms also typically have a broader footprint on the surrounding environment. The larger the farm the higher the potential to export non-point source pollution into waterways. In Austin, urban farms (again, classified as farms over one acre) average only 4.5 acres in total land area, and, moreover, the actual plots that produce food occupy fewer acres. Often embedded within the total land area are woods, pasture, and fallow ground. If these areas remain undeveloped they may occupy space where HSAs are located. Hence, potential urban farms using BMPs and occupying space around future development in the two researched watersheds can provide valuable community benefits in the form of providing access to healthy food, enriching green space, and protecting prime farmland, as well as the added environmental benefit of leaving HSAs as undeveloped land.

\subsection{Opportunities at the Local Scale}

The situation at Green Gate Farms in Elm Creek watershed offers an instructive view of the pressures current and potential urban farms confront as development encroaches into the rural-urban fringe of Austin. In addition, Green Gate Farms shows the value urban farms bring to a community and why urban agriculture in the City of Austin should be considered as a valuable land management tool.

Green Gate Farm is an organic farm occupying five acres of leased land on a larger parcel of land that also contains a large RV park and undeveloped land. The land sits in an area experiencing major growth with the construction of new subdivisions. An informal interview with one of the farmers provided the following information. The farmers of the land have been farming on it for the last 10 years paying rent to one owner. Recently, the land was sold to a new owner who hopes to develop an upscale RV park and manufactured homes on the farmstead. Until recently, the two original farmers lived on the land in an old farmhouse, but a new condition applied by the current landowner stipulated that the house can longer be used as a residence, forcing the farmers to move off the land. The farmhouse now operates as an office for the farm and a non-profit called New Farm Institute with a mission "to educate, assist and inspire citizens and a new generation of sustainable farmers, with a focus on the urban fringe" [45]. Currently, the farmers are still under lease until summer 2016 and continue to operate the farm, but whether or not they will be able to continue to farm the land is uncertain.

Furthermore, the farmer indicated that the mission of the farm has always been community oriented. As former health professionals, the farmers' priorities have been to provide fresh produce to underserved families living in a part of east Austin that is recognized by the USDA as a food desert, an area with limited access to fresh food or existing one mile or more from a grocery store [46]. As part of the mission to create a community resource for neighbors of all incomes, the farm accepts Supplemental Nutrition Assistance Program (SNAP) benefits (i.e. food stamps) and Women, Infants, and Children (WIC) vouchers so that 
citizens in the community can buy healthy local produce. In addition, the farm has a robust community supported agriculture (CSA) program that provides boxes of organic produce, meat, eggs, and flowers to participating individuals that choose to enroll in a weekly, monthly, or yearly subscription service. During an on-site observation of the farm, it became clear that community involvement is something that is not just talked about, but actually exists. Many people dropped by on a Saturday afternoon to purchase certified organic vegetables, dairy, meat, and eggs from the farm stand, which is open to the public Tuesday, Friday and Saturday. At least two families purchased produce with food benefit cards. In addition, they have an open-door policy that allows the public to experience a working urban farm providing educational opportunities as wells as a relaxing environment. On this particular Saturday, the farm hosted a children's birthday party surrounded by volunteers and workshare members preparing the fields for Fall planting.

To protect beneficial urban farms like Green Gate Farm and ensure that future urban agricultural opportunities exist on prime farmland within the suburban DDZ, the Austin Sustainable Food Policy Board (SFPB) serve as advisors to the Austin City Council and the Travis County Commissioners Court to improve the food system in Austin. As part of the land development code update in Austin (CodeNEXT), the all-volunteer SFPB working group is working with community and board members"to improve upon the existing code in a way that meets the needs of communities, farmers, and regulators in the interest of a healthy, safe, secure, and sustainable food system for all of Austin" [47]. The group's work includes providing recommendations on desirable land use policies in the suburban DDZ [47] (below):

- Prioritize preservation of prime farmland;

- Establish limits on sub-dividing farmland;

- Utilize community gardens in new housing developments;

- Allow for conversion of underutilized industrial sites/strip-malls into urban farms.

The Green Infrastructure working group in Austin is also currently working on integrating green infrastructure as part of land development code update to meet the provisions set forth in the Imagine Austin Comprehensive Plan. The SFPB working group and the Green Infrastructure working group both provide paths by which their recommendations can be integrated into the code revision process and ensure that urban agriculture is considered a viable asset in the updated land development code. The methods outlined in this research to delineate HSAs on potential urban agricultural sites as a green infrastructure strategy could prove useful to both working groups as they look for ways to conserve portions of Austin's green space.

For example, consider the situation at Green Gate Farm again: while the five acre farmstead does not contain any prime farmland soils nor HSAs, the undeveloped fields next to the farm do contain 2.2 acres of HSAs on prime farmland that are not protected under the CWQZ. If an updated land development code existed establishing land use controls that "prioritized preservation of prime farmland" to include HSAs as a part of the criteria that functions as green infrastructure tool in the WPO then a portion of this land could be protected from development and potentially be used as urban agriculture site. Under this type of land management scenario there could be an opportunity to move Green Gate Farm onto the adjacent prime farmland that occupies the HSAs in order to preserve environmental and social functionality and services offered by the farmstead when the new owner builds the RV Park. The protection of Green Gate Farm would serve not only the underserved communities' needs with continued healthy fresh produce but also provide critical watershed protection from the incoming development.

\subsection{Limitations of the Research}

The ability to remotely prioritize HSAs and potential urban agriculture sites is one advantage of employing a GIS based approach as opposed to the costly and time consuming practice of visiting all sites. While the soil data collected provides the necessary components to complete the soil topographic index, it would be ideal to have on-site collected data of the soil infiltration rates and soil depths associated with urban agricultural land in east Austin, enabling a comparative analysis that quantifies exactly how much urban farms help to reduce stormwater runoff. Furthermore, ground truthing HSAs on the prioritized sites to verify that there is a potential for surface runoff would further validate the GIS based approach of delineating HSAs. Additionally, 2014 aerial imagery from NAIP was used to verify selected sites in this study where cultivated cropland could be recognized as potential urban agricultural land. It is also possible to ground truth data using Google Earth, similarly to Taylor and Lovell [48], who used this method to identify backyard agriculture in Chicago. Nonetheless, before making any policy decisions, on-the-ground site-checking of selected HSAs on potential urban farms should be a necessary component of any urban agriculture land inventory [13].

Another possible limitation of this study are the derived threshold criteria determining the HSAs in both watersheds. In this study, the threshold criteria for selecting HSAs are TI values greater than or equal to 1.5 standard deviations above the mean. This approach follows well-researched methods from Mickle et al. [37] and Qui [39] who use similar derivations. However, more information is needed on the local characteristics of the watersheds in Austin that could possibly determine a more suitable threshold value. This could result in either leaving the value the same, or increasing or decreasing the delineations of HSAs in the study area depending on if that value is equal to, greater than, or less than the value used in this study.

Another limitation of the study is the lack of analysis of other important factors related to the feasibility of urban agriculture. When determining land use for future development, urban agriculture faces strong competition from housing and commercial developers; simply creating urban farms instead of housing or businesses could decrease affordable housing options or minimize job creating commercial devel- 
opments. Like the set of BMPs urban farms use to mitigate stormwater runoff, BMPs should also be created that properly locate urban agriculture without hindering access to affordable housing.

\section{Conclusion}

While urban agriculture is a valuable tool in a city's toolbox of methods which can be used to create a more sustainable city, it is by no means a solution to all the problems a city endures. This study will add only one piece of knowledge to an ongoing discussion and debate about urban agriculture's role in developing more sustainable cities. Nevertheless, this research may help to further establish urban agriculture as part of the discussion about strategies that could lead to a more sustainable city. The social and economic benefits of urban agriculture are well established and well known, but the scientific inquiry into the environmental benefits of urban agriculture is still lagging behind current needs and popular enthusiasm. This research aims to add a spatially explicit method to urban agriculture's potential as a green infrastructure strategy that demonstrates the ability of urban farms to mitigate surface runoff and provide environmental benefits to a city. By validating urban agriculture as green infrastructure it will help to integrate urban agriculture into public policy and urban planning as a land management strategy.

\section{References and Notes}

[1] Summary of the Clean Water Act: EPA Laws and Regulations. U.S. Environmental Protection Agency. Available from: http://www.epa. gov/laws-regulations/summary-clean-water-act.

[2] Combined Sewer Overflows (CSOs): National Pollutant Discharge Elimination System (NPDES). U.S. Environmental Protection Agency. Available from: http://www.epa.gov/npdes/combined-seweroverflows-csos.

[3] What is Green Infrastructure? U.S. Environmental Protection Agency. Available from: http://www.epa.gov/green-infrastructure/what-greeninfrastructure.

[4] Lovell ST. Multifunctional Urban Agriculture for Sustainable Land Use Planning in the United States. Sustainability. 2010;2(8):2499-2522. doi:10.3390/su2082499.

[5] Mougeot LJA. Growing better cities: urban agriculture for sustainable development. Choice Reviews Online. 2007;43. doi:10.5860/choice.44-2695.

[6] Mendes W, Balmer K, Kaethler T, Rhoads A. Using Land Inventories to Plan for Urban Agriculture: Experiences From Portland and Vancouver. Journal of the American Planning Association. 2008;74(4):435-449. doi:10.1080/01944360802354923.

[7] Vitiello D. Growing Edible Cities. In: Birch E, Wachter S, editors. Growing Greener Cities. Philadelphia, PA, USA: University of Pennsylvania Press. 10.9783/9780812204094.259.

[8] Brownfields and Urban Agriculture: Interim Guidelines for Safe Gardening Practices. U.S. Environmental Protection Agency. Available from: http://www.epa.gov/sites/production/files/2015-09/documents/ bf_urban_ag.pdf.

[9] Dunn AD. Siting Green Infrastructure: Legal and Policy Solutions to Alleviate Urban Poverty and Promote Healthy Communities. Boston, MA, USA: Pace Law Faculty Publications; 2010. Available from: http://digitalcommons.pace.edu/cgi/viewcontent.cgi?article= 1557\&context=lawfaculty.

[10] Pothukuchi K, Kaufman JL. The Food System. Journal of the American Planning Association. 2000;66(2):113-124. doi:10.1080/01944360008976093.

[11] Malczewski J. GIS-based multicriteria decision analysis: A survey of the literature. International Journal of Geographical Information Science. 2006;20(7):703-726. doi:10.1080/13658810600661508.

[12] Horst M. Review of Suitable Urban Agriculture Land Inventories. American Planning Association. Journal of the American Planning Association. 2011;Available from: https://planning-org-uploaded-media.s3.amazonaws.com/ legacy_resources/resources/ontheradar/food/pdf/horstpaper.pdf.

[13] Erickson DL, Lovell ST, Méndez VE. Identifying, quantifying and classifying agricultural opportunities for land use planning. Landscape and Urban Planning. 2013;118:29-39. doi:10.1016/j.landurbplan.2013.05.004.

[14] Balmer K, Gill J, Kaplinger H, Miller J, Peterson M, Rhoads A, et al. The Diggable City: Making Urban Agriculture a Planning Priority. Mas-

ter of Urban and Regional Planning Workshop Projects. 2016;Paper 52. Available from: http://pdxscholar.library.pdx.edu/cgi/viewcontent. cgi?article=1051\&context=usp_murp.

[15] Park JR, Stabler MJ, Mortimer SR, Jones PJ, Ansell DJ, Parker GPD. The use of a multiple criteria decision analysis to evaluate the effectiveness of landscape and habitat enhancement mechanisms: An example from the South Downs. Journal of Environmental Planning and Management. 2004;47(5):773-793. doi:10.1080/0964056042000274470.

[16] Arnstein SR. A Ladder Of Citizen Participation. Journal of the American Institute of Planners. 1969;35(4):216-224. doi:10.1080/01944366908977225.

[17] McClintock N, Cooper J. Cultivating the Commons-An Assessment of the Potential for Urban Agriculture on Oakland's Public Land. Berkeley, CA, USA: Department of Geography, University of California; 2010. Available from: http://www.web.pdx.edu/ ncm3/files/ Cultivating_the_Commons2010.pdf.

[18] Zhang FF, Cai J, G L. How urban agriculture is reshaping peri-urban Beijing? Open House International. 2009;34(2):15-24.

[19] Chin D, Infahsaeng T, Jakus I, Oorthuys V. Urban Farming in Boston: A Survey of Opportunities. Boston, MA, USA: Tufts University. Available from: http://as.tufts.edu/uep/sites/all/themes/asbase/assets/ documents/fieldProjectReports/2013/Team_8_Final_Report_2013.pdf.

[20] Ackerman K. The Potential for Urban Agriculture in New York City: Growing Capacity, Food Security, and Green Infrastructure. New York, NY, USA: Urban Design Lab, Columbia University; 2012. Available from: http://urbandesignlab.columbia.edu/files/2015/04/ 4_urban_agriculture_nyc.pdf.

[21] Kremer P, DeLiberty TL. Local food practices and growing potential: Mapping the case of Philadelphia. Applied Geography. 2011;31(4):1252-1261. doi:10.1016/j.apgeog.2011.01.007.

[22] Myeong S, Nowak D, Hopkins P, Brock R. Urban cover mapping using digital, high-spatial resolution aerial imagery. Urban Ecosystems. 2001;5(4). 10.1023/A:1025687711588. 10.1023/A:1025687711588.

[23] McClintock N, Cooper J, Khandeshi S. Assessing the potential contribution of vacant land to urban vegetable production and consumption in Oakland, California. Landscape and Urban Planning. 2013;111:4658. doi:10.1016/j.landurbplan.2012.12.009.

[24] Horst M. Growing Green: An inventory of Public Lands Suitable for Community Gardening in Seattle, Washington. Seattle, WA, USA: University of Washington; 2008. Available from: http://www.seattle.gov/Documents/Departments/Neighborhoods/ PPatch/Growing-Green.pdf.

[25] Colasanti K. Assessing the local food supply capacity of Detroit, Michigan. Journal of Agriculture, Food Systems, and Community Development. 2010;pp. 41-58. doi:10.5304/jafscd.2010.012.002.

[26] McClintock N. Assessing soil lead contamination at multiple scales in Oakland, California: Implications for urban agriculture and environmental justice. Applied Geography. 2012;35(1-2):460-473. doi:10.1016/j.apgeog.2012.10.001.

[27] Imagine Austin Comprehensive Plan. City of Austin, TX, USA. Available from: https://austintexas.gov/sites/default/files/files/Planning/ 
ImagineAustin/webiacpreduced.pdf.

[28] Top Ten Demographic Trends in Austin, Texas. City of Austin, TX, USA. Available from: https://www.austintexas.gov/page/top-tendemographic-trends-austin-texas.

[29] State of the Food System Report. City of Austin, TX, USA. Available from: http://austintexas.gov/sites/default/files/files/Sustainability/ AustinFoodReport050115_-_FINAL.pdf.

[30] Karvonen A. Politics of Urban Runoff. Cambridge, MA, USA: MIT Press; 2011.

[31] Watershed Ordinance History: Watershed Protection Ordinance Stakeholder Process 2011-2012. City of Austin, TX, USA. Available from: https://web.archive.org/web/20130915093925/http: //austintexas.gov/page/watershed-protection-ordinance.

[32] Watershed Ordinance History. City of Austin, TX, USA. Available from: https://web.archive.org/web/20130915093925/http:// austintexas.gov/page/watershed-protection-ordinance.

[33] Community Inventory: Natural Environment. City of Austin, TX, USA. Available from: http://ftp://ftp.ci.austin.tx.us/GIS-Data/planning/compplan/ combined_community_inventory_NaturalEnvironment_v7.pdf.

[34] What is Urban Agriculture? U.S. Environmental Protection Agency. Available from: http://www3.epa.gov/region1/eco/uep/ urbanagriculture.html.

[35] Environmental Integrity Index. City of Austin, TX, USA. Available from: http://www.austintexas.gov/department/environmentalintegrity-index.

[36] Agnew LJ, Lyon S, Gérard-Marchant P, Collins VB, Lembo AJ, Steenhuis TS, et al. Identifying hydrologically sensitive areas: Bridging the gap between science and application. Journal of Environmental Management. 2006;78(1):63-76. doi:10.1016/j.jenvman.2005.04.021.

[37] Martin-Mikle CJ, de Beurs KM, Julian JP, Mayer PM. Identifying priority sites for low impact development (LID) in a mixeduse watershed. Landscape and Urban Planning. 2015;140:29-41. doi:10.1016/j.landurbplan.2015.04.002.

[38] Qiu Z, Hall C, Drewes D, Messinger G, Prato T, Hale K, et al. Hydrologically Sensitive Areas, Land Use Controls, and Protection of Healthy Watersheds. J Water Resour Plann Manage. 2014;140(7):04014011. doi:10.1061/(asce)wr.1943-5452.0000376.
[39] Qiu Z, Hall C, Drewes D, Messinger G, Prato T, Hale K, et al. Hydrologically Sensitive Areas, Land Use Controls, and Protection of Healthy Watersheds. J Water Resour Plann Manage. 2014;140(7):04014011. doi:10.1061/(asce)wr.1943-5452.0000376.

[40] Evans J, Oakleaf J, Cushman S, Theobald D. Quantitative Methods in Spatial Ecology: An ArcGIS Toolbox for Surface Gradient and Geomorphometric Modeling. Version 2.0-0. Available from: http://evansmurphy.wix.com/evansspatial\#!arcgis-gradientmetrics-toolbox/crro.

[41] Municode Library: Critical Water Quality Zones Established. City of Austin, TX, USA. Available from: https://www.municode.com/library/ tx/austin/codes/code_of_ordinances?nodeld=TIT25LADE_CH258EN_SUBCHAPTER_AWAQU_ART2WACLZOES.

[42] Walter M, Walter M, Brooks E, Steenhuis T, Boll J, Weiler K. Hydrologically sensitive areas: Variable source area hydrology implications for water quality risk assessment. Journal of Soil and Water Conservation. 2000;3:227-284.

[43] Boian M, Hughes J, Deardorff L. Urban Farms: A Green Infrastructure Tool for the Chesapeake Bay. American Rivers; 2015. Available from: http://www.americanrivers.org/assets/pdfs/reports-andpublications/UrbanAgricultureReport_Final.pdf.

[44] Tip 244: Urban Agriculture. City of Seattle, WA, USA. Available from: http://www.seattle.gov/DPD/Publications/CAM/cam244.pdf.

[45] Green Gate Farms. New Farm Institute. Available from: http: //greengatefarms.net/new-farm-institute.

[46] Food Access Research Atlas, U.S. Department of Agriculture. Available from: http://www.ers.usda.gov/data-products/food-accessresearch-atlas/go-to-the-atlas.aspx.

[47] Recommendation To Code Next From The Sustainable Food Policy Board. City of Austin, TX, USA. Available from: https:/www.austintexas.gov/sites/default/files/files/ Planning_and_Zoning/CodeNEXT/Sustainable_Food_Policy_Board_ RecommendationToCodeNext.pdf.

[48] Taylor JR, Lovell ST. Mapping public and private spaces of urban agriculture in Chicago through the analysis of high-resolution aerial images in Google Earth. Landscape and Urban Planning. 2012;108(1):57-70. doi:10.1016/j.landurbplan.2012.08.001. 